\title{
É COM PESAR QUE INFORMAMOS O ENCERRAMENTO DE NOSSAS ATIVIDADES: REPRESENTAÇÕES E PRÁTICAS DO DECLÍNIO ORGANIZACIONAL EM VIDEOLOCADORAS
}

\author{
WE ARE SORRY TO INFORM THE END OF OUR ACTIVITIES: \\ REPRESENTATIONS AND PRACTICES OF THE \\ ORGANIZATIONAL DECLINE IN VIDEO RENTAL STORES
}

\section{ES CON PESAR QUE INFORMAMOS EL CIERRE DE NUESTRAS ACTIVIDADES: REPRESENTACIONES Y PRÁCTICAS DE LA DECLINACIÓN ORGANIZACIONAL DE COMPAÑÍAS DE SERVICIO DE ALQUILER DE PELÍCULAS}

Vanessa Alves Pinhal

Mestre em Administração pela Universidade Federal de Uberlândia (UFU) / Tutora na Faculdade do Trabalho (FATRA), Brasil

vanessa-pinhal@hotmail.com

Daniel Victor de Sousa Ferreira

Mestre em Administração pela Universidade Federal de Uberlândia (UFU) / Bacharel em Administração pela Universidade Federal de Viçosa (UFV), Brasil thunder.danvic@hotmail.com

\section{Jacquelaine Florindo Borges}

Professora Adjunta da Universidade Federal de Uberlândia (UFU) / Doutora em Administração pela Universidade de São Paulo (FEA/USP) / Mestre em Administração pela Universidade Federal de Uberlândia (UFU), Brasil

jac.borges@uol.com.br
Contextus

ISSNe 2178-9258

Organização: Comitê Científico Interinstitucional Editor Científico: Diego de Queiroz Machado

Avaliação: double blind review pelo SEER/OJS Edição de texto e de layout: Carlos Daniel Andrade

Recebido em 09/08/2017

Aceito em 25/03/2018

$2^{\mathrm{a}}$ versão aceita em 11/04/2018

\section{RESUMO}

Este artigo analisa as representações sociais e as práticas estratégicas de gestores de videolocadoras em relação às tensões relacionais micro/macro que caracterizam o declínio dessas organizações. A partir da perspectiva da estratégia como prática, a pesquisa foi conduzida pela abordagem qualitativa. Para a coleta de dados foram utilizadas a técnica de entrevista e uma técnica projetiva com proprietários das videolocadoras. A análise de conteúdo foi empregada para tratar os resultados da tensão relacional e dos elementos da agência humana: iterativo, projetivo, prático-avaliativo. Os resultados mostram que gestores prático-avaliativos realizam mudanças buscando melhoria de resultados e estão atentos aos desafios, enquanto gestores iterativos continuam trabalhando como sempre trabalharam, atendendo os poucos e fidelizados clientes, sendo indiferentes às adversidades. A despeito de práticas estratégicas distintas, na dimensão projetiva, os gestores compartilham uma imagem: a morte das videolocadoras. Assim, a estratégia enquanto prática social abarca temáticas da mudança e do declínio organizacionais enquanto vivência (antecipada) do luto nas organizações.

Palavras-chave: Estratégia como Prática. Representações Sociais. Mudança organizacional. Declínio organizacional. Resiliência organizacional.

\section{ABSTRACT}

This article aims to analyze social representations and strategic practices of video rental store managers with respect to the micro/macro relational tensions that characterize the decline of such organizations. From a perspective that conceives of strategy as practice, the research was conducted within a qualitative approach. 
Concerning the data collection, interviews and a projective technique with video rental store owners were used. The content analysis was applied to deal with the relational tension results and the elements of human agency: iterative, projective, evaluative-practical. The results demonstrate that evaluative-practical managers make changes while seeking better results and are careful with challenges, whereas iterative managers continue to work as they always did, by serving a few loyal clients and being indifferent to adversity. In spite of different strategic practices, managers share an image in the projective dimension: the death of video rental stores. Thus, strategy as a social practice encompasses themes of organizational change and decline as (anticipated) experience of mourning in organizations.

Keywords: Strategy as Practice. Social Representations. Organizational Change. Organizational Decline. Organizational Resilience.

\section{RESUMEN}

Este artículo analiza las representaciones sociales y las prácticas estratégicas de gestores de compañías de servicio de alquiler de películas respecto a las tensiones relacionales micro/macro que caracterizan el declive de tales compañías. Desde la perspectiva de la estrategia como práctica, se condujo la investigación por medio del enfoque cualitativo. Se utilizaron entrevistas y una técnica proyectiva con propietarios de tales compañías. Se empleó el análisis del contenido en el análisis de los resultados de tensión relacional y de los elementos de la agencia humana: iteración, proyección, práctica evaluativa. Los resultados muestran, mientras que los gestores práctico-evaluativos realizan cambios buscando mejorar los resultados y están atentos a los desafíos, los gestores iterativos continúan trabajando como siempre han trabajado, atendiendo a los pocos y fieles clientes, además siendo indiferentes a las adversidades. A pesar de las prácticas estratégicas distintas, en la dimensión proyectiva, los gestores comparten una imagen: la muerte de las compañías de servicio de alquiler de películas. Así, la estrategia como práctica social abarca temáticas de cambio y del declive organizacional como vivencia (anticipada) del luto en las organizaciones. Palabras-clave: Estrategia como Práctica. Representaciones Sociales. Cambio Organizacional. Declive Organizacional. Resiliencia Organizacional.

\section{INTRODUÇÃO}

A gente lutou muito. Sempre acreditávamos que haveria uma estratégia que poderíamos tentar [...], mas as opções foram se esgotando, sem resultado (Diretora e proprietária da 2001 Vídeo. In: COLOMBO, 2015).

Reportagem intitulada "Os últimos dos moicanos" chamou a atenção para a situação de cerca de 3.000 locadoras existentes no Brasil (LIMA, 2015), número que já chegara a ser de 14.000. No final de 2015, a rede 2001 Vídeo anunciou o encerramento das atividades das lojas físicas (COLOMBO, 2015). Há 33 anos no mercado, a tradicional rede de locadoras enviou mensagem para os clientes - "É com pesar que informamos o encerramento de nossas atividades nas lojas da rede física da 2001 Vídeo" (PORTAL TERRA, 2015).

O mercado audiovisual de vídeo doméstico ou home video é composto por empresas cuja atividade principal é o serviço de locação e a venda de DVDs, discos Blu-Ray e outras mídias com conteúdo audiovisual. O negócio de videolocadoras é orientado para oferecer aos consumidores obras audiovisuais em suportes de mídia pré-gravados (ANCINE, 2010). Nos anos 1990, especialmente com a mudança da tecnologia VHS (Video Home System) para DVD (Digital Video Disc), a locação apresentava-se como boa opção para os usuários, devido à facilidade de escolher o que e quando assistir, fazendo 
emergir novos negócios e comportamentos (SILVA; LOPES; OLIVEIRA, 2013).

Nas últimas décadas, o mercado de vídeo doméstico sofreu um processo de virtualização (FILHO et al., 2014; HERMANN, 2012; LIMA, 2015; SILVA; LOPES; VIEIRA, 2013) que afetou as práticas de produção, distribuição e consumo de entretenimento. A popularização da Internet facilitou o acesso, a criação, a distribuição e o consumo de bens e serviços audiovisuais. Novas possibilidades de distribuição de conteúdo audiovisual passaram a ser utilizadas como, por exemplo, o vídeo sob demanda (video on demand), oferecido pelas empresas de TV a cabo ou por satélite.

Mudanças tecnológicas são protagonizadas por novos concorrentes, provedores independentes e gigantes do setor como Netflix, Now, Amazon. Também ocorreu uma inegável mudança no comportamento do consumidor, mais interessado naquilo que está em voga nas redes sociais, diferente do comportamento dos cinéfilos, tradicionais frequentadores das videolocadoras que estavam dispostos a passar horas em uma locadora garimpando filmes e dedicando tempo para assisti-los e debatê-los (COLOMBO, 2015; FILHO et al., 2014; LIMA, 2015).

A queda nas vendas físicas, nos últimos anos, é explicada pelo surgimento de novos modelos de negócios como, por exemplo, o streaming (forma de distribuição de dados em que as informações são disponibilizadas onde e quando o usuário/consumidor deseja acessá-lo, conforme empregado por Netflix, YouTube, HBOGo, TelecinePlay, Warner, Sony, Globo), o pay-per-view (aquisição de uma programação específica a qual se deseja assistir como, por exemplo, nos canais Telecine e HBO) e outros. No final de 2016, estimativas indicavam 6 milhões de assinantes no Brasil para a empresa Netflix (CASTRO, 2016). Em 2017, a empresa superou 100 milhões de assinantes, a maioria fora dos EUA (BRADSHAW, 2017). Nos últimos anos, a empresa tem investido na produção de conteúdo e em estúdios de produção na Europa.

Com a expansão da Internet, as videolocadoras correm o risco de se tornarem obsoletas ou extintas, visto que o processo de virtualização influencia de maneira direta a rentabilidade das videolocadoras. Ou seja, por meio da Internet os usuários conseguem fazer downloads de lançamentos e também compartilhar esses arquivos, muitas vezes por meio de reprodução e comercialização não autorizada (ANCINE, 2010). O aumento da pirataria, facilitado pela disseminação da Internet por banda larga, também contribuiu para queda nas vendas e 
locações (FILHO et al., 2014;HERMANN, 2012; LIMA， 2015; SILVA; LOPES; VIEIRA, 2013).

Esta pesquisa parte desse cenário que parece impor às videolocadoras a extinção ou a necessidade de se reinventarem. Adaptações geralmente ocorrem em três situações principais: ajustar-se devido à falta de mudanças por parte da empresa durante muitos anos; adequar-se às questões que exigem modificações; e corrigir aquilo que não está mais funcionando nas empresas tradicionais (GONÇALVES, 1998). Tal cenário, todavia, mostra a luta pela sobrevivência das videolocadoras em um estágio de declínio organizacional cujas causas elas não podem controlar.

Nesse contexto, a literatura da estratégia (MINTZBERG; AHSTRAND; LAMPEL, 2000), especialmente no caso das escolas prescritivas (design, planejamento e posicionamento), indicarão a necessidade, por parte das organizações, de analisar a indústria, de redirecionar-se estrategicamente e de adaptar-se às mudanças ambientais. Por sua vez, as políticas governamentais e os fóruns empresariais (escola empreendedora) destacarão a necessidade de uma atuação empreendedora dos gestores nas videolocadoras. Destes espera-se que reconheçam os impactos das ideias inovadoras (escola cognitiva) e não continuem a repetir um padrão de comportamento estratégico (escola ambiental) e, além disso, que se preparem para aprender a aprender (escola do aprendizado), em um ambiente que exige frequentes adaptações.

A estratégia como prática (strategyas-practice) se interessa pelos sujeitos e pelo contexto (NICOLINI, 2009; SEIDL; WHITTINGTON, 2014), ou seja, as micropráticas são socialmente situadas. Considerando essa abordagem, o problema desta pesquisa é como as macroinfluências são interpretadas e construídas no nível micro da agência humana. $O$ objetivo é analisar as representações sociais e as práticas estratégicas de gestores de videolocadoras frente às tensões relacionais micro-macro provocadas por novos concorrentes, inovações tecnológicas e mudanças no comportamento do consumidor, uma situação problemática em um cenário que impõe necessidade de reinventar os negócios de vídeos domésticos.

Este artigo está estruturado em outras sete seções, além da presente introdução. A seguir, são apresentados aspectos relevantes sobre o mercado audiovisual e sobre as videolocadoras. Posteriormente trata-se das representações sociais e da relação entre os níveis de 
análise, micro e macro, na perspectiva da estratégia como prática. Em seguida, são apresentados os procedimentos metodológicos, a discussão dos resultados e as conclusões.

\section{REFERENCIAL TEÓRICO}

No campo da administração, a metáfora do organismo "oferece uma forma eficiente de ver a estratégia e o planejamento organizacional" e estimula "ver que populações inteiras de organizações podem surgir e desaparecer juntamente com as transformações dos nichos e dos fluxos de recursos" (MORGAN, 2000, p. 53). Entre as contribuições da metáfora do organismo está o conceito de ciclo de vida (nascimento, crescimento, maturidade, declínio): do produto, da organização e da indústria.

Em relação ao ciclo de vida da organização e ao declínio organizacional, Whetten (1980) argumentou que se negligenciavam a pesquisa e o ensino sobre o declínio, o que se podia explicar por uma ideologia em prol do crescimento da organização. O ciclo de vidaorganizacional também é tratado pela literatura organizacional a partir de estágios, sendo o declínio o último.
Este, por seu turno, caracteriza-se por diferentes estágios próprios (WEITZEL; JONSSON, 1989): (1) cegueira da organização: o problema é que os gestores não reconhecem os sinais de ameaça à sobrevivência da organização, e a solução é criar sistemas de informação, avaliação e acompanhamento que mostrem quando algo vai mal; (2) inação: o problema é que os gestores continuam negando a deterioração do desempenho organizacional, e a solução é identificar o que está errado e adotar práticas e tomar decisões que alinham a organização com o ambiente; (3) ação falha: o problema está na falha das decisões ou na sua implementação, e a solução é enfrentar e empreender as grandes mudanças; (4) crise: o problema é a instalação do caos e do pânico devido à incerteza, e a solução deve envolver a estratégia e a cultura organizacionais; (5) dissolução: o problema é que a crise e a incerteza ambiental, bem como a lenta resposta da organização tornam o declínio inevitável, sendo a solução para a perda de mercado, de funcionários, de reputação e de capital planejar o encerramento das atividades da organização.

Em geral, a imagem do declínio está associada com disfunções ou atributos organizacionais e gerenciais negativos. Cameron, Whetten e Kim (1987) 
analisaram o conjunto de disfunções organizacionais que a literatura sobre o assunto considera como efeitos e atributos negativos do declínio. Aqueles autores identificaram diferenças na presença desses atributos em organizações privadas e públicas e de pequeno e grande porte.

Em análise sobre o declínio organizacional, Cameron e Zammuto (1983) propõem uma tipologia composta de uma matriz com quatro quadrantes com origem em dois eixos e quatro situações. Eis os eixos: (1) continuidade e descontinuidade de mudança ambiental; (2) mudança no tamanho do nicho e mudança no tipo de nicho. Os quatro quadrantes são: (1) erosão: a mudança contínua do ambiente e a mudança no tamanho do nicho podem levar a uma situação de estagnação dos conflitos; (2) contração: conflitos que ameaçam a sobrevivência relacionados à mudança descontínua do ambiente e à mudança no tipo de nicho; (3) dissolução: mudança contínua do ambiente e mudança no tipo do nicho podem requerer a contenção dos conflitos; (4) colapso: os conflitos são gerados e potencializam a confusão geral devido à mudança descontínua do ambiente e à mudança no tipo do nicho.

Em estudo que ressalta a necessidade de distinguir declínio, turbulência e estagnação, Cameron, Kim e
Whetten (1987) afirmam que o declínio organizacional e as turbulências ambientais têm efeitos distintos sobre a ação dos top managers (centralização, não realização do planejamento de longo prazo, cortes não seletivos e outros) e sobre a reação dos membros da organização (perda de credibilidade, queda do moral, resistência à mudança, dentre outros). As diferentes consequências do declínio para as organizações também são analisadas por D’Aveni (1989), dentre elas a paralisia estratégica.

O interesse pelo tema do declínio, nos anos 1980, desenvolveu-se por diferentes grupos de estudiosos: o declínio associado ao ciclo de vida da indústria e aquele ligado ao ciclo de vida da organização ocuparam, respectivamente, o campo da estratégia e o dos estudos organizacionais. Os estudos do ciclo de vida organizacional e do declínio adotam uma concepção orgânica, com ênfase na relação interativa (e adequada) da organização com o ambiente como condição para "a vida e a sobrevivência” organizacionais; tal metáfora do organismo mantém uma visão modernista relacionada ao funcionalismo (MORGAN, 1980).

A forte tendência prescritiva da literatura sobre ciclo de vida e declínio organizacional (CAMERON; ZAMMUTO, 1983), bem como a visão de estratégia como 
algo que a empresa possui e como atribuição exclusiva da alta direção recebem fortes críticas epistemológicas da perspectiva da estratégia como prática, orientada por pressupostos neointerpretativistas e neoestruturalistas (RASCHE; CHIA, 2009). Mesmo reconhecendo essas críticas, o conceito de ciclo de vida da indústria e da organização foi resgatado no presente artigo para que se pudesse contemplar a temática do declínio organizacional no setor de videolocadoras.

\subsection{O mercado audiovisual e as videolocadoras}

A cadeia produtiva do mercado audiovisual é constituída por atividades de produção, distribuição e exibição, sendo composta pelos estúdios ou distribuidoras, pelos cinemas e pelas videolocadoras (Figura 1). As distribuidoras detêm os direitos de comercialização das obras audiovisuais, algumas delas ligadas aos grandes estúdios (como a Sony, Disney e Warner). Elas são as responsáveis por disponibilizar as obras para os estabelecimentos que atuam na ponta da cadeia produtiva, como as videolocadoras, que oferecem o produto ao consumidor final (ANCINE, 2010).

Figura 1 - Estrutura da cadeia do setor audiovisual

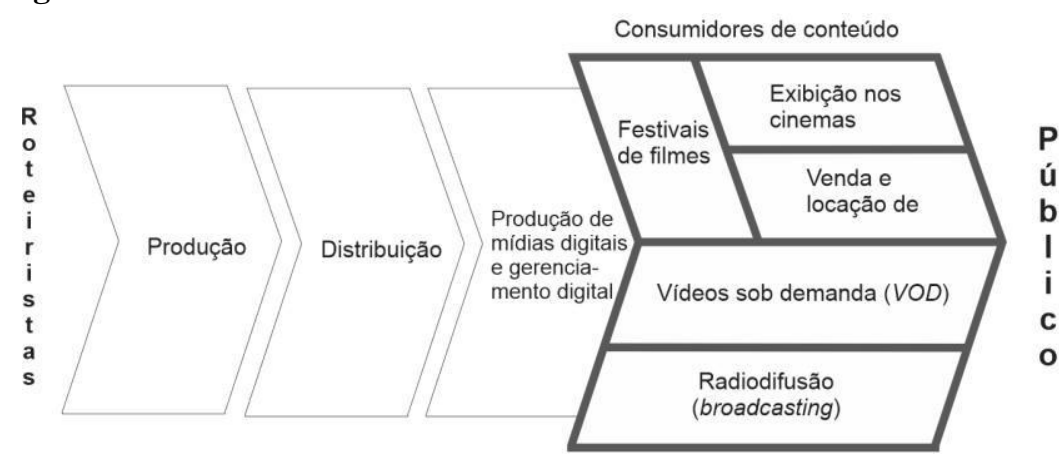

Fonte: adaptado de Ancine (2010) e Nordicity (2013).

De maneira geral, a exibição nos cinemas é o primeiro canal de distribuição. Em seguida, o filme torna-se disponível para locação ou compra em meios físicos (DVD ou Blu-Ray), canais pay-per-view, video-on-demand e em outros meios.
Finalmente, a exibição é realizada em TVs por assinatura e na TV aberta (FILHO et al., 2014). As videolocadoras se inserem no segmento de mercado de vídeo doméstico que "representa o conjunto de atividades encadeadas, realizadas por diversos agentes 
econômicos, necessários para ofertar ao consumidor final [...] obras audiovisuais em qualquer suporte de mídia pré-gravada" (ANCINE, 2010, p. 4).

O mercado de vídeo doméstico desempenhou papel importante para os estúdios durante muitos anos. No contexto norte-americano, era possível perceber que, na década de 1980, 30\% da lucratividade da indústria tinha origem nos cinemas. Por volta dos anos 2000, o cenário mudou, com o setor de home video dominando a fonte de lucros (CHIOU, 2006). No Brasil, as videolocadoras começaram a atuar na década de 1980 com a aquisição dos primeiros videocassetes, apresentando um rápido aumento no número de aparelhos. Por volta de 1998, o DVD substituiu as fitas VHS, e as videolocadoras estavam no auge no Brasil (LIMA, 2015).

O costume de assistir a vídeos alterou o comportamento dos brasileiros no que se refere à busca por entretenimento, criando novas oportunidades de negócios (SILVA; LOPES; VIEIRA, 2013).

Entretanto, entre 2007 e 2014, adiminuição da locação de DVDs, a popularização da TV a cabo, o acesso a filmes e seriados pela Internet com banda larga, a persistente pirataria, o custo de aluguel em locais estratégicos, o gasto com a formação de funcionários e a crise econômica provocaram o fechamento de dois terços de todas as locadoras existentes no Brasil (COLOMBO, 2015; PORTAL TERRA,

2015). Para sobreviverem no mercado, as videolocadoras têm adotado estratégias além do aluguel, como venda de filmes, sistema de franquias, videolocadoras virtuais (telefone ou Internet), utilização de máquinas de autoatendimento (ANCINE, 2010) e serviços de conversão de antigas fitas VHS para DVD (LIMA, 2015).

Apesar do irreversível processo de virtualização e do surgimento de novos negócios que oferecem filmes, séries e produção original on-line, ainda é possível perceber a existência de mercado para as videolocadoras. Em estudo sobre as mudanças no comportamento dos consumidores no que se refere a "desmaterialização" dos produtos, Hermann (2012), usando o caso da empresa Netflix, verificou ser ainda possível notar motivos para que determinados consumidores não mudem hábitos cotidianos, continuando a alugar vídeos fisicamente. Ademais, conforme pesquisa realizada pelo IBGE, nota-se que, no ano de 2012, apenas $10,7 \%$ dos municípios brasileiros possuíam cinema, contribuindo para que as pessoas recorressem à locação de vídeos (IBGE, 2012). Outros três motivos para a longevidade das videolocadoras são: $\mathrm{o}$ aluguel de jogos, pois o consumidor de videogames nem sempre 
pode comprar os jogos que deseja; a discrepância entre alto preço e baixa velocidade da banda larga no Brasil; e a possibilidade das videolocadoras se tornarem cool (LIMA, 2015), vistas como espaços para se encontrarem raridades e gêneros de filmes desprezados pelos outros canais (TV e provedores), bem como voltadas para um público específico que rejeita a "ditadura" e a "pasteurização" do ramo (COLOMBO, 2015).

\subsection{Representações sociais da estratégia}

As representações individuais e coletivas emergem e orientam as ações dos indivíduos nas interações cotidianas, podendo ser conceituadas, portanto, como eventos individuais, através de representações mentais em que o social é o contexto, conforme afirma Spink (1993). Ele situa as representações sociais (RS) no campo da psicologia social e as considera fenômenos sociais (1993, p. 300), porque "mesmo acessados a partir do seu conteúdo cognitivo", esses fenômenos "têm de ser entendidos a partir do seu contexto de produção". Desse modo, as RS são não apenas socialmente compartilhadas, mas, também, socialmente elaboradas. Ao mesmo tempo em que as RS emergem dos indivíduos, também orientam suas ações nas interações cotidianas, por meio das “funções simbólicas e ideológicas a que servem e das formas de comunicação em que circulam" (SPINK, 1993, p. 300).

Diversos autores assumiram o papel de transpor estudos e conceitos da sociologia para a psicologia social (DURAN, 2012). Dentre eles, Moscovici (2007, p. 9) concebeu o fenômeno de RS com base na psicanálise e na sociologia (retomando os estudos de Durkheim). Uma RS, nesse sentido, consiste na maneira de as pessoas partilharem o conhecimento e constituírem uma realidade comum, ao transformarem ideias em práticas, “através da interação e comunicação". As RS “nos guiam no modo de nomear e definir conjuntamente os diferentes aspectos da realidade diária, no modo de interpretar esses aspectos, tomar decisões e, eventualmente, posicionar-se frente a eles [...]" (JODELET, 2001, p. 17).

O conceito de RS permeia um campo transdisciplinar de estudos (SPINK, 1993). Por exemplo, diversos autores circunscrevem o conceito ao campo dos estudos organizacionais, ao pesquisarem: as representações do feminino e masculino no trabalho de garçons e garçonetes (DINIZ; CARRIERI; BARROS, 2013), o trabalho confinado na indústria petrolífera (SALLES; COSTA, 2013), as questões de gênero em jornais de circulação interna de 
duas empresas (CORREA et al., 2007), o lucro no comércio de artigos religiosos (ENOQUE; BORGES; BORGES, 2014), a convivência de diversos grupos em um centro comercial (FIGUEIREDO; CAVEDON, 2012), a organização, o papel do administrador e as práticas de gestão em cursos de graduação em administração (BORGES; MEDEIROS; CASADO, 2011).

Nos estudos de estratégia, por sua vez, Cavedon e Ferraz (2005) relacionam as RS com pequenos comércios, discorrendo sobre a dualidade entre o saber institucionalizado da estratégia e as (res)significações atribuídas a esse conhecimento no cotidiano organizacional de pequenos comerciantes. Guerra e Tatto (2010) relacionam a RS com a perspectiva da estratégia como prática no contexto gerencial de organizações familiares do ramo de hotelaria. Afirmam que as práticas da estratégia são influenciadas por RS que os gerentes têm sobre a própria estratégia. Carrieri et al. (2012) também estudam as estratégias e táticas empreendidas por pequenas organizações familiares para sobreviver às mudanças contextuais ao longo de quase um século.

O conceito de RS pode oferecer um caminho teórico-metodológico para os estudos da estratégia como prática social (SILVA; CARRIERI; JUNQUILHO,
2011), dado ser uma alternativa para compreender os limites contextuais que envolvem o fazer das pessoas, dentro e fora das organizações. Tal concepção corresponde à visão relacional de macro- e micro-práticas, visto que os níveis macro e micro "coexistem em uma tensão relacional de constituição e explicação mútua, interagindo por meio de uma gama de fatores intermediários"

(WILSON; JARZABKOWSKI, 2004, p. 16).

\subsection{A tensão relacional entre os níveis micro e macro}

Tradicionalmente, a estratégia tem sido tratada como uma propriedade das organizações (WHITTINGTON, 2006; JOHNSON et al., 2003; JARZABKOWSKI; WHITTINGTON, 2008), em perspectivas amplas que, por vezes, negligenciam os fenômenos que ocorrem em um nível "micro", como as atividades cotidianas que permeiam as rotinas organizacionais (JOHNSON et al., 2007).

$\mathrm{Na}$ tentativa de preencher essa lacuna, surge a abordagem da estratégia como prática, com foco nos estrategistas e no "fazer estratégia" (WHITTINGTON, 1996). Os estudos nessa perspectiva concentram sua atenção nas atividades cotidianas dos atores das organizações e no 
modo como esses atores e suas atividades interagem com o contexto no qual estão inseridos (JARZABKOWSKI, 2003). A estratégia como prática possui uma posição única no campo da gestão estratégica devido à sua habilidade de conexão entre análises de contextos micro e macro (VARA; WHITTINGTON, 2012).

Apesar da necessidade de considerar as microatividades desempenhadas pelos diversos atores das organizações, torna-se relevante enfatizar a contextualização das microações. Em outros termos, os microfenômenos precisam ser compreendidos em seu contexto social mais amplo, pois os atores não estão interagindo de forma isolada, mas sofrendo influência das pluralidades das instituições sociais a que pertencem (JARZABKOWSKI; BALOGUN; SEIDL, 2007). Ao reconhecer a necessidade de incluir uma análise com visão mais micro, Johnson et al. (2003) também citam a necessidade de colocar o nível micro dentro do macro, com o intuito de descobrir relações plausíveis para o desempenho e ainda oferecer guias tangíveis para ações gerenciais.

Nessa perspectiva, Wilson e Jarzabkowski (2004) propõem a tensão relacional em que os níveis micro e macro se constituem dois polos a interagir por meio de diversos fatores intermediários. No nível da macroanálise, destacam-se as instituições sociais, econômicas e políticas, enquanto podem ser citados, no nível micro, os discursos, as práticas e os gestos. Dessa forma, considera-se que as práticas ocorrem tanto em contextos amplos que proporcionam comunalidades de ação, quanto em microcontextos, ou seja, elas ocorrem dentro de uma interação fluida entre os contextos micro e macro (JARZABKOWSKI, 2004).

Dentre as vantagens de estabelecer uma conexão entre o nível micro e macro, Seidl e Whittington (2014) enfatizam uma compreensão mais holística do "fazer estratégia" e a oferta de uma base mais substancial para alegações teóricas sobre a relevância dos limites de determinadas práticas estratégicas. São necessários uma integração e um movimento alternado entre uma visão ampla e outra mais restrita, possibilitando entender melhor como as práticas locais participam nas grandes configurações e como entram com seus elementos e recursos em outras atividades (NICOLINI, 2009).

A perspectiva relacional foge do reducionismo. Os autores destacam que ambos os níveis são bidirecionados, já que qualquer atividade que aconteça estará relacionada tanto ao contexto macro quanto ao micro. Nessa visão, os resultados e as influências são compreendidos tal como nas teorias institucionais e em estudos com foco 
no nível industrial (WILSON;

JARZABKOWSKI, 2004). Nota-se o

esforço de estabelecer, nas pesquisas da estratégia como prática, um avanço em direção a propostas de conexões mais efetivas das atividades estratégicas locais e os fenômenos sociais mais amplos, ou seja, as práticas dos sujeitos e as práticas dos contextos (NICOLINI, 2009; SEIDL; WHITTINTON, 2014). A estratégia como prática se interessa, portanto, por uma dimensão da agência humana relacionada com a capacidade prático-avaliativa (WILSON; JARZABKOWSKI, 2004).

Conforme Emirbayer e Mische (1998, p. 971), existem três elementos constitutivos da agência humana (pensamento e ação) que caracterizam "a capacidade dos atores de modelarem criticamente sua própria capacidade de reagir a situações problemáticas": iteração - quando os atores recompõem padrões de pensamento e ação do passado, capazes de trazer ordem e estabilidade ao universo social e de ajudar a sustentar identidades, interações e instituições; resposta projetiva - quando os atores geram imagens de trajetórias futuras possíveis da ação, e seu pensamento e sua ação são reconfigurados criativamente em relação a um futuro temido e/ou desejado por eles; resposta prático-avaliativa - quando os atores fazem julgamentos práticos e normativos entre trajetórias alternativas possíveis de ação em resposta a situações que envolvem demandas emergentes, dilemas e ambiguidade. Os mesmos autores argumentam que, a despeito dessas distinções analíticas, os três elementos ou dimensões que fundamentam a agência humana formam uma tríade e existem em graus diferentes conforme a situação empírica em questão.

\section{PROCEDIMENTOS METODOLÓGICOS}

Esta pesquisa foi conduzida por uma abordagem qualitativa e guiada por pressupostos ontológicos e epistemológicos do interpretativismo e da estratégia como prática (DENZIN; LINCOLN, 2010; RASCHE; CHIA, 2009), sendo caracterizada como empírica (FELDMAN; ORLIKOWSKI, 2011). Para a coleta de dados foram realizadas entrevistas episódicas, indicadas para estudos cujo objetivo se relaciona com o conhecimento do cotidiano, em que, através das seleções das situações, os entrevistados contam, por meio de narrativas e argumentos, o seu ponto de vista, objetivando extrair do entrevistado as definições e narrativas (FLICK, 2003).

Conforme o Quadro 1, realizaram-se 10 entrevistas com os proprietários de 
videolocadoras da cidade de Uberlândia. Neste artigo, os entrevistados estão identificados pelo símbolo $E$, como forma de garantir a confidencialidade do gestor. A seleção intencional foi aplicada para definir o público da pesquisa (SILVERMAN, 2009). Inicialmente, buscou-se identificar as videolocadoras ativas por meio de catálogos e páginas em redes sociais. Posteriormente, foi feito o contato para o agendamento da entrevista com os proprietários das empresas que se disponibilizaram a participar da pesquisa.

Quadro 1 - Perfil dos entrevistados

\begin{tabular}{|l|l|l|l|}
\hline Entrevistado & Idade & Escolaridade & Tempo de atuação no setor \\
\hline$E_{1}$ & 39 & Ensino Médio Incompleto & 10 anos \\
\hline$E_{2}$ & 62 & Ensino Médio Incompleto & 28 anos \\
\hline$E_{3}$ & 60 & Ensino Médio Completo & 14 anos \\
\hline$E_{4}$ & 42 & Ensino Médio Completo & 18 anos \\
\hline$E_{5}$ & 27 & Engenheiro de Produção & 8 anos \\
\hline$E_{6}$ & 39 & Ensino Superior em Administração & 22 anos \\
\hline$E_{7}$ & 31 & Técnico em Gestão e Tecnologia & 3 anos \\
\hline$E_{8}$ & 40 & Ensino Médio Incompleto & 15 anos \\
\hline$E_{9}$ & 57 & Ensino Médio Completo & 21 anos \\
\hline$E_{10}$ & 60 & Ensino Superior Completo & 30 anos \\
\hline
\end{tabular}

Fonte: elaborado pelos autores.

Além da entrevista episódica, foi utilizada a técnica projetiva de construção de desenhos, com vistas a estimular manifestações emocionais e psicológicas, pouco privilegiadas por técnicas de cunho racional (VERGARA, 2006). Métodos de coleta de material visual auxiliam na identificação de semelhanças e diferenças dos tipos de ação e interação cotidianas (SILVERMAN, 2009). Foi solicitado aos entrevistados que realizassem um desenho sobre o futuro das videolocadoras. Dos 10 entrevistados, 4 não se sentiram à vontade para fazer o desenho, mas expuseram sua representação do futuro verbalmente. Após a realização e o registro das entrevistas em áudio, estas foram transcritas, e o corpus de pesquisa, analisado por meio da Análise de Conteúdo (BARDIN, 1977), considerando o conceito de tensão relacional micromacro (WILSON; JARZABKOWSKI, 2004) e as três dimensões da agência: iterativa, projetiva e prático-avaliativa (EMIRBAYER; MISCHE, 1998). 


\section{APRESENTAÇÃO E ANÁLISE DOS RESULTADOS}

As entrevistas mostraram que as RS são essencialmente heterogêneas (SPINK, 1993). Foi possível identificar contradições e diversidades de ideias. Entretanto, certos significados do contexto social compartilhados pelos proprietários de videolocadoras baseavam-se em elementos mais estáveis. Isso ocorre porque, além do consenso, o próprio senso comum é composto por diversidades, "pois algo sempre sustenta uma determinada ordem social: pressupostos de natureza ideológica, epistémes historicamente localizadas ou, até mesmo, ressonâncias do imaginário social" (SPINK, 1993, p. 306).

No total de dez videolocadoras pesquisadas, não foi possível encontrar outro perfil de empresa, senão microempreendimentos familiares gerenciados pelo proprietário. Todos os gestores entrevistados são do sexo masculino, a maioria dos quais estudou até o ensino médio, tinha mais de 40 anos e atuava no mercado audiovisual havia mais de 10 anos, conforme Quadro 1. Também foi possível identificar que todos foram motivados a iniciar suas atividades no mercado devido a uma oportunidade de negócio que surgira na história pessoal de cada um.
Na década de 1990 e início dos anos 2000, o mercado era visto como promissor, e as videolocadoras eram notadas pela grande quantidade de clientes que as frequentavam. Os entrevistados $\mathrm{E}_{1}, \mathrm{E}_{2}, \mathrm{E}_{3}$, $\mathrm{E}_{5}, \mathrm{E}_{6}, \mathrm{E}_{8}$ e $\mathrm{E}_{9}$ enfatizaram essa questão. $\mathrm{O}$ gestor $E_{4}$ e o $E_{10}$ citaram que o motivo que os levou a atuar no ramo, até os dias atuais, foi a paixão por jogos e filmes. Quanto ao entrevistado $\mathrm{E}_{7}$, diferentemente dos demais, ele explicou que já possuía um negócio que oferecia serviços de informática e apenas incluiu o serviço de locação de vídeos por ter percebido a inexistência de videolocadoras no bairro.

\subsection{Análise da tensão relacional micro-macro no setor de videolocadoras}

$\mathrm{Na}$ análise das entrevistas, as RS que emergem nos relatos dos gestores de videolocadoras mostram a construção de sentido sobre o que acontece no mercado. Tais informações são acessadas de modo cognitivo e afetivo por meio das redes sociais, consultas na Internet, conversas com os clientes e acompanhamento de acontecimentos do cinema. Os entrevistados lamentam a escassez de boas revistas especializadas de outrora, pois atualmente só é possível encontrar uma quantidade pequena de conteúdo on-line e 
algumas revistas de fornecedores de DVDs e Blu-Ray.

Todos os entrevistados enfatizaram uma considerável queda na quantidade de locações, e alguns ainda discorrem sobre as dificuldades financeiras desse tipo de comércio, o que explica o encerramento das atividades de muitas grandes redes. Os entrevistados avaliam que as videolocadoras ainda ativas dependem basicamente dos clientes mais antigos que ainda gostam de frequentá-las para obter as informações dos filmes pessoalmente e ter certa proximidade com o proprietário. Os entrevistados identificaram as seguintes macroinfluências para o seu negócio de videolocadoras.

a) Internet: é destacada como um concorrente desleal, quanto ao acesso que as pessoas têm aos filmes, pois é possível encontrá-los antes de chegarem às locadoras e, muitas vezes, sem custo, no caso de reprodução ilegal. Apesar da baixa qualidade nesses casos, existem clientes que não se importam com o fato e trocam as videolocadoras pela Internet. A fala de E2 destaca esses pontos e ainda a cultura e situação política do país.

O que nos atrapalha e o que vai continuar atrapalhando até o final, que não tem retorno, é a Internet. Porque até hoje eu não entendi o que uma pessoa ganha para entrar na Internet, digamos [...] esse povo que coloca esses filmes... mal saiu do cinema, coloca lá na Internet, não ganham nem um centavo para isso; para que? (E2) b) Pirataria: foi possível identificar dois tipos de pirataria, citadas pelos entrevistados: a física, de pessoas que vendem em feiras e nas ruas; e a pirataria on-line. Para a maioria dos gestores, a física influencia pouco, principalmente devido à qualidade muito baixa. Entretanto, destacam-se dois públicos que costumam fazer uso desse tipo de produto: as pessoas com baixa condição financeira $\mathrm{e}$ as crianças, que não dão muito valor à qualidade. Já no caso da pirataria on-line, é unânime o impacto que traz para seus negócios, pois influencia toda a cadeia de distribuição e com isso, as videolocadoras. Ao tratar sobre o tema, E5 e E10 mencionam esse processo. Ainda, ao tratar sobre a pirataria física, E10 relata que se sente intimamente violado pela pirataria, pois as pessoas costumavam alugar os filmes na própria locadora para fazerem cópias para vender. Ele cita que registrou diversos boletins de ocorrência devido a esse tipo de conduta. É uma cadeia de atos ilegais que levam a outros, daí a importância da luta contra a pirataria.

Então, quando você corta esse caminho no ilegal - baixar um filme que nem saiu pra cinema ainda, você simplesmente corta toda uma cadeia, aí você não vai no cinema porque você já viu [...] aí você não vai na locadora. (E5)

Se não fosse a luta para o combate à pirataria o ramo já teria morrido. Eventos, campanhas antipirataria [...] quem não deixou esse ramo ir mais rápido 'para o buraco' foi Ministério Público, Poder Judiciário. (E10) 
c) Vídeo sob demanda (VOD) e TV a cabo: com relação ao serviço específico do VOD, a maioria dos entrevistados destaca que não impacta significativamente sobre o negócio devido ao valor ser superior ao da locação, então o cliente somente contrata caso realmente preze pela comodidade de não sair de casa. Canais como $\mathrm{HBO}$ e Telecine (pay-per-view) ainda possuem influência menor e, em alguns casos, até ajudam as videolocadoras devido aos horários em que transmitem os filmes, como é destacado em uma das falas.

\section{[...] a questão dos canais fechados e do Telecine, de certa forma até que ajuda para $\mathrm{mim}$, porque tem muita gente que às vezes tem em casa, mas vê um filme lá que vai passar e não consegue assistir naquele horário ou não gosta de ver propaganda. Então a pessoa chega aqui [...] e aí eu consigo locar. (E7)}

d) Provedores de séries e filmes: estes são vistos como concorrentes, porém sem interferir fortemente no negócio. Todos os entrevistados destacam o acervo mais antigo e o foco nos seriados. Essa informação é relevante, já que se pôde perceber, nas videolocadoras analisadas, que a maioria dos clientes procuram por lançamentos. Além disso, um dos entrevistados destaca a Netflix não apenas como concorrente, mas também como oportunidade: ele idealizou uma ação com base na estratégia adotada por essa empresa visando fidelizar mais clientes:
[...] então a pessoa paga 3 meses de mensalidade e fica pegando filmes ilimitados igual Netflix [...]. O diferencialé que a gente ainda consegue receber filmes antes do que essas produtoras, o Netflix hoje. (E5)

De maneira geral, apesar de algumas videolocadoras empreenderem ações para lidar com os desafios impostos pelo mercado, a maioria não julga possível combatê-los e, com isso, permanece sem fortes esperanças de sobrevivência. Seja como for, a presente pesquisa identificou duas formas de agência sustentadas em distintas representações sociais, conforme o Quadro 2. A análise considerou as três dimensões que fundamentam a agência humana (pensamento e ação) ou a capacidade de os atores lidarem criticamente com situações problemáticas: iterativa, projetiva e prático-avaliativa (EMIRBAYER; MISCHE, 1998, p. 971).

$\mathrm{Na}$ pesquisa com os gestores de videolocadoras, duas dimensões da ação humana estudadas por Emirbayer e Mische (1998) se destacam. Todos os gestores representam a situação do negócio de videolocadoras como dramática e crítica (dimensão projetiva). Porém, alguns entrevistados representam a situação problemática em que atuam de tal modo que lhes resta continuar apenas trabalhando como sempre trabalharam, atendendo os poucos e fidelizados clientes - representada pela figura do gestor iterativo. 
Enquanto isso, outros entrevistados mantêm-se atentos à situação e ao mercado, buscando ações que possam lhes proporcionar uma melhor situação competitiva - representada pela figura do gestor prático-avaliativo. O perfil de gestão mais recorrente nas falas dos entrevistados é oriundo da dimensão iterativa da ação gestor iterativo. Entretanto, dada a abordagem qualitativa do estudo, oobjetivo não foi quantificar a fala dos gestores, mas evidenciar as vozes existentes.

Ainda que o ponto de partida seja "a diversidade dos indivíduos, atitudes e fenômenos" (MOSCOVICI, 2007), visto que essas locadoras estão localizadas em bairros distintos e atendem a diferentes públicos, a pesquisa mostra que as $\mathrm{RS}$ da tensão relacional entre micro e macro produzem imagens estáveis e até previsíveis desse momento experimentado pelos proprietários-gestores de videolocadoras. Em momentos de crise, as imagens e expressões são mais vivas, porque as memórias coletivas são excitadas e o comportamento é mais espontâneo. Daí decorre o papel fundamental das RS como meios de recriar a realidade (MOSCOVICI, 2007) e de edificar conduta, opinião e atitude (JODELET, 2001).

Conforme sugerido por Spink (1993), depois de buscar elementos mais estáveis e compartilhados, buscou-se pelo que há de contraditório, sendo possível identificar nas falas dos entrevistados os distintos elementos da ação humana (EMIRBAYER; MISCHE, 1998) que correspondem a diferentes RS, sobressaindo-se o gestor interativo e o gestor prático-avaliativo. Desse modo, além das RS, foi possível identificar distintas práticas situadas na tensão relacional entre os níveis micro e macro (WILSON; JARZABKOWSKI, 2004) do mercado de videolocadoras. Portanto, é seguro afirmar que as RS abordadas na presente pesquisa influenciam a adoção de determinadas práticas estratégicas. 
Quadro 2 - Representações e práticas dos gestores de videolocadoras frente às tensões micro-macro.

\begin{tabular}{|c|c|c|}
\hline $\begin{array}{c}\text { Fontes da } \\
\text { tensão micro- } \\
\text { macro }\end{array}$ & Gestor iterativo & Gestor prático-avaliativo \\
\hline Internet & $\begin{array}{l}\text { Representação: forte demais para ser } \\
\text { combatida; promove a pirataria e outras formas } \\
\text { de entretenimento. } \\
\text { Prática estratégica: fica inerte e não promove } \\
\text { o uso da Internet nos negócios. }\end{array}$ & $\begin{array}{l}\text { Representação: pode ajudar muito na } \\
\text { divulgação e em campanhas } \\
\text { promocionais. } \\
\text { Prática estratégica: utiliza redes } \\
\text { sociais e pratica promoções. }\end{array}$ \\
\hline Pirataria & $\begin{array}{l}\text { Representação: forte demais para combater } \\
\text { sem ajuda do Estado. } \\
\text { Prática estratégica: fica inerte aguardando a } \\
\text { ação do Estado. }\end{array}$ & $\begin{array}{l}\text { Representação: não interfere muito } \\
\text { porque não tem qualidade e promove } \\
\text { riscos legais. } \\
\text { Prática estratégica: investe em filmes } \\
\text { de alta qualidade e legalizados. }\end{array}$ \\
\hline Netflix & $\begin{array}{l}\text { Representação: não interfere (indiferente) } \\
\text { porque ainda é considerada uma alternativa } \\
\text { cara e/ou porque não possui todos os filmes, } \\
\text { como os últimos lançados no cinema. } \\
\text { Prática estratégica: fica inerte - não há o que } \\
\text { esperar ou o que fazer porque está tudo } \\
\text { conforme a lei. }\end{array}$ & $\begin{array}{l}\text { Representação: interfere pouco devido } \\
\text { ao acervo antigo. } \\
\text { Prática estratégica: investe na alta } \\
\text { qualidade dos filmes e/ou na compra de } \\
\text { filmes considerados "lançamentos", } \\
\text { acompanhando as tendências do } \\
\text { cinema. }\end{array}$ \\
\hline $\begin{array}{l}\text { TV por } \\
\text { assinatura e } \\
\text { vídeo sob } \\
\text { demanda (VOD) }\end{array}$ & $\begin{array}{l}\text { Representação: não interfere porque o custo } \\
\text { do serviço é elevado. } \\
\text { Prática estratégica: fica inerte - não há o que } \\
\text { esperar ou o que fazer porque está tudo } \\
\text { conforme a lei. }\end{array}$ & $\begin{array}{l}\text { Representação: não interfere porque o } \\
\text { custo do serviço é elevado. } \\
\text { Prática estratégica: investe na compra } \\
\text { de lançamentos de alta qualidade para } \\
\text { garantir competitividade. }\end{array}$ \\
\hline $\begin{array}{l}\text { A organização } \\
\text { (empresa) }\end{array}$ & $\begin{array}{l}\text { Representação: a empresa é vista como } \\
\text { símbolo de uma época em que as prazerosas e } \\
\text { longas conversas sobre cada filme valiam a ida } \\
\text { à locadora e eram uma forma de estar } \\
\text { atualizado em relação ao mundo do cinema. } \\
\text { Prática estratégica: não sendo possível } \\
\text { retornar àquela época e fazer frente às } \\
\text { implacáveis mudanças em tecnologia, } \\
\text { concorrência e comportamento do consumidor, } \\
\text { resta aguardar e viver dignamente os últimos } \\
\text { momentos das videolocadoras. }\end{array}$ & $\begin{array}{l}\text { Representação: a empresa é vista } \\
\text { como um negócio que deve ser viável, } \\
\text { apesar dos desafios enfrentados com as } \\
\text { mudanças em tecnologia, concorrência } \\
\text { e comportamento do consumidor. } \\
\text { Prática estratégica: buscar práticas } \\
\text { estratégicas alternativas que } \\
\text { possibilitem o enfrentamento dos } \\
\text { desafios competitivos que marcam o } \\
\text { setor de videolocadoras. }\end{array}$ \\
\hline
\end{tabular}

Fonte: elaborado pelos próprios autores.

\subsubsection{Gestor iterativo}

Esse perfil de gestão é caracterizado

pela predominância da dimensão iterativa

da agência (EMIRBAYER; MISCHE,

1998), em que a representação da situação

problemática do negócio de videolocadoras

gera indiferença às adversidades oriundas do macroambiente. Esses gestores realizam as locações de obras audiovisuais e atendem seus clientes da melhor maneira possível, mas não acreditam que a situação irá mudar. Por isso, esperam o momento em que não terão mais possibilidade de atuar, com a empresa inevitavelmente encerrando as atividades. Eles acreditam que os 
investimentos, como ligar para clientes informando sobre as novidades, participar de divulgações ou patrocínios, já não trazem mais retorno. Com isso, não realizam nenhuma ação para aumentar vendas ou atrair novos clientes.

Dentre os que acreditam que o fim das videolocadoras está próximo, um dos entrevistados enfatiza que a única solução, em sua percepção, é a mudança de setor. Ele não tem esperança de que o mercado reaqueça, inclusive porque o próprio comportamento das pessoas mudou. Outro entrevistado, o E10, cita que mantém a videolocadora porque gosta, mas acrescentou no mesmo espaço uma lanchonete e usa os clientes da videolocadora para os lanches. As falas selecionadas abaixo retratam aspectos relacionados a essas percepções.

[...] as pessoas perderam [...] o sentido de família. De você sentar, para assistir [sic] um filme, conversar, até debater sobre o filme. (E6)

[...] todo mundo está desistindo. Assim, uns 2 anos atrás, por causa da pirataria. Hoje a Internet está tomando conta, sabe? Tem muita TV a cabo, essas coisas também [...] tem Netflix, tem... Sky" (E9).

O filme, antes de chegar no cinema, ele já está disponível na Internet. (E3)

A gente vai perdendo a graça [...] não fiz mais propaganda, eu tentei pegar o público [fidelizar o cliente] da locadora ao enriquecer o lanche. (E10)

Com relação à Internet, como acreditam que as pessoas não ficam mais sem o uso dela, os gestores continuam gerindo seu negócio da mesma forma sem mudanças. Para eles, o real problema trazido pela Internet foi a promoção da pirataria. Como não é possível agir contra ela sozinhos, nada pode ser feito. Eles destacam que as denúncias não surtem efeito e esperam ações mais efetivas por parte do Estado e das autoridades responsáveis, como pode ser observado em uma das falas, do E1.

Nós queremos pedir socorro. Socorro para as autoridades, não sei quais autoridades que podem nos ajudar. Vocês que são os estudantes que vão mais além, vocês que são o futuro do Brasil [...] Então nós pedimos socorro para vocês para que nós fiquemos de pé. Se você é aquela pessoa que não tem condições, talvez, de pagar uma TV paga aí, que está supercaro, assim, uma videolocadora serve com o preço mais acessível para todo mundo locar um filme. Então socorro aí, gente! (E1)

A pirataria é vista, portanto, como o maior desafio e o maior vilão pelos gestores desse perfil. A empresas como Netflix e Amazon, apesar de sua popularidade, esses gestores são indiferentes, o mesmo valendo para os serviços oferecidos por TVs a cabo.

Assim, as RS desse perfil de gestor estão associadas às adversidades do ambiente econômico e institucional (macro) e à impossibilidade, insuficiência ou inutilidade de qualquer ação no nível da videolocadora (micro) para reverter o processo de virtualização, os novos modelos de negócios e a mudança no comportamento dos consumidores 
(COLOMBO, 2015, FILHO et al., 2014; HERMANN, 2012; LIMA, 2015). As RS desse perfil mostram que as tensões entre micro e macro resultaram em um rompimento entre o antigo e o novo no mercado de vídeos domésticos, e esse vazio não pode ser preenchido sem que se promova uma "revolução concreta no senso comum" (MOSCOVICI, 2007, p. 91) dos proprietários-gestores de videolocadoras. A rejeição à venda de produtos como "bichinhos de pelúcia” (PORTAL TERRA, 2015) explica-se porque tal fato é visto como perda de identidade social, antes compartilhada, desses indivíduos (JODELET, 2001).

\subsubsection{Gestor prático-avaliativo}

O perfil prático-avaliativo de gestão é caracterizado pela predominância daquela dimensão da agência, em que as representações das adversidades do ambiente econômico e institucional estimulam ações criativas (EMIRBAYER; MISCHE, 1998). Nesse perfil, também se destaca a pirataria como o maior desafio. Todavia, essa representação da pirataria gera $o$ investimento em ações para promover o aumento das locações e fidelizar os clientes. Para esse tipo de gestor, apesar de a Internet promover a pirataria on-line, ela também é vista como oportunidade para divulgar as ações da videolocadora e informar-se sobre o mercado. Ele acredita e investe na inovação, na qualidade das mídias e no oferecimento de outros produtos como jogos e programas de fidelidade ou pacotes promocionais.

Então infelizmente ela está entrando numa queda, mas você tem que... se você quer se manter vivo, e for a sua intenção, você tem que inovar. Tem que tentar buscar coisas novas. (E5)

[...] tem a questão das redes sociais também, que eu consigo divulgar e acabo tendo um retorno maior com isso. Ao mesmo tempo que ela atrapalha um pouco, também beneficia. (E7)

Assim como esse perfil consegue enxergar oportunidades na Internet, também o faz com as empresas que trouxeram novos modelos de negócios e digitalizaram o mercado de vídeo doméstico. Quando a concorrência é legal, como ocorre com a Netflix, a Amazon e os serviços de TV a Cabo, é mais fácil para o gestor prático-avaliativo lidar com esses concorrentes e criar artifícios para superálos do que tentar fazer o mesmo com a pirataria on-line, considerada desleal.

[...] não me preocupo com Netflix, eu acho que atrapalha um pouquinho, sim, mas é concorrência, então você tem... concorrência legal você usa ela [...] como uma ferramenta pra você crescer de um outro lado [...]. (E5)

Sendo assim, nota-se que as ações desse perfil são mais voltadas para promoções e visões sobre o que pode ser mudado e melhorado diante das atuais circunstâncias. Esse perfil enxerga as 
adversidades como uma oportunidade de crescimento e de reinserção na emergente dinâmica social, o que explica a especificidade dessas representações (JODELET, 2001). A RS tem como função manter a identidade social e o equilíbrio sociocognitivo a ela relacionado. Por isso, após tentarem evitar a novidade (elemento estranho ou desconhecido) incontornável, os indivíduos desenvolvem ações e práticas cujo objetivo é "torná-la familiar" e "integrá-la ao universo do pensamento préexistente" no ambiente social e ideal (JODELET, 2001, p. 35). Esse perfil do gestor prático-avaliativo desenvolve uma representação da virtualização do mercado de vídeos domésticos como algo que não eliminará ou extinguirá suas videolocadoras, mesmo que tenham de modificar a sua forma de atuação e apesar da alta probabilidade de se reduzir a quantidade desses empreendimentos.

\subsection{A mesma dimensão projetiva e ações heterogêneas: a morte como uma perspectiva de futuro comum}

$\mathrm{Na}$ seção anterior, evidenciou-se o caráter prático das RS para o entendimento da agência humana (pensamento e ação) de gestores de videolocadoras que lidam com uma situação problemática gerada por uma forte tensão micro-macro no ramo de vídeos domésticos. Dado que a dimensão iterativa e a prático-avaliativa se destacaram nas entrevistas com os gestores de videolocadoras, a dimensão projetiva da agência humana, relacionada às projeções imaginativas do futuro temido e/ou desejado, tem papel menos significativo. Projetar a morte do próprio negócio em um futuro próximo não gera para os gestores entrevistados um terceiro perfil. Com efeito, os gestores iterativos e os práticoavaliativos já trabalham com essa representação do declínio dos negócios de vídeos domésticos.

As ações dos gestores iterativos e dos prático-avalitativos são distintas: cada tipo age de acordo com os significados construídos, o conhecimento sobre seu negócio e sobre o mercado, bem como as suas expectativas de inserção na nova dinâmica econômica e social. É importante ressaltar que qualquer gestor pode adotar ora ações do gestor prático-avaliativo, ora ações do gestor interativo. Essas duas dimensões - iterativa e prático-avaliativa -, juntamente com a projetiva, formam uma tríade que fundamenta a ação humana, mas, de modo geral, as três não coexistem de forma harmoniosa, podendo apresentar diferentes graus conforme a situação empírica problemática da ação. Esta pesquisa mostrou que uma imagem do futuro é compartilhada pelos gestores: a RS de um futuro semelhante, que seria a morte 
do setor de videolocadoras conforme ele se constituiu nos anos 1990. Por isso, a extinção desse segmento de locação de vídeos é uma possibilidade para todos os entrevistados e, para alguns, uma certeza.

[o caso das videolocadoras] é um problema sem solução; não existe solução. A solução, a única solução é mudar de ramo... tanto é que eu estou mudando de ramo. (E6)

Em muitas falas, foi possível observar citações sobre a quantidade de videolocadoras que fecharam ou estão fechando. Por isso, uma possibilidade representada seria a locação on-line (ecommerce), o que significa de qualquer forma $o$ fim das videolocadoras tradicionais. Verificou-se uma melhora na quantidade de locações após o encerramento de alguns sites ilegais que ofereciam filmes on-line, entretanto não foi suficiente para fazer voltar a quantidade de clientes. Muitos estabelecimentos empregavam vários funcionários, mas hoje os proprietários trabalham sozinhos para conseguirem manter o negócio. Dos entrevistados, apenas um ainda emprega funcionários na loja.

Enquanto alguns investem em lançamentos para manter e continuar atraindo clientes, outros não o fazem devido ao custo mais elevado. Todos afirmam que o negócio já foi muito rentável e a queda no movimento e nas locações em geral reduziu-se de maneira significativa, a ponto de diversas lojas fecharem ao longo dos anos na cidade.

[...] eu fico de "banho-maria" só mais para conversar e seguir em frente. [...] Moro aqui, então tudo é tranquilo. [...] hoje, as locadoras estão todas fechando justamente porque não souberam esquematizar e não souberam planejar a parte financeira, o fluxo de caixa e tudo o mais [...] (E2).

Então surgiram várias coisas para concorrer com locadora que não aguenta. Quem paga aluguel para manter a locadora hoje, está tudo fechando. Eu mantenho aqui porque o imóvel é meu e eu não pago aluguel (E3). Eu locava 300 filmes em um sábado, hoje eu loco 30, 40. Caiu 90\%. (E3)

Ao serem questionados sobre a possibilidade de recomendar a abertura de um negócio de locação de vídeos, houve uma unanimidade negativa devido a todas as dificuldades já expostas anteriormente. $\mathrm{O}$ que poderia acontecer, na avaliação de um dos entrevistados, é a junção do negócio de locação com outro (diversificação), como ele já o faz. Para os gestores entrevistados, existem alguns acontecimentos que, se concretizados, beneficiariam o mercado como um todo e, como consequência, seu próprio negócio. Dentre eles se destacam: o fim da pirataria, em todas as suas formas; uma fiscalização mais rígida por parte das autoridades responsáveis; o fechamento do Netflix; a criação de novos dispositivos, superiores ao DVD ou BluRay, já que este último não obteve sucesso e a procura é mínima; a redução de impostos na compra dos filmes; data de lançamento mundial, pois contribuiria para o fim da pirataria on- 
line; e a volta do hábito de assistir a filmes

em casa com a família.

Figura 2 - O futuro das videolocadoras em desenhos produzidos por proprietários-gestores.

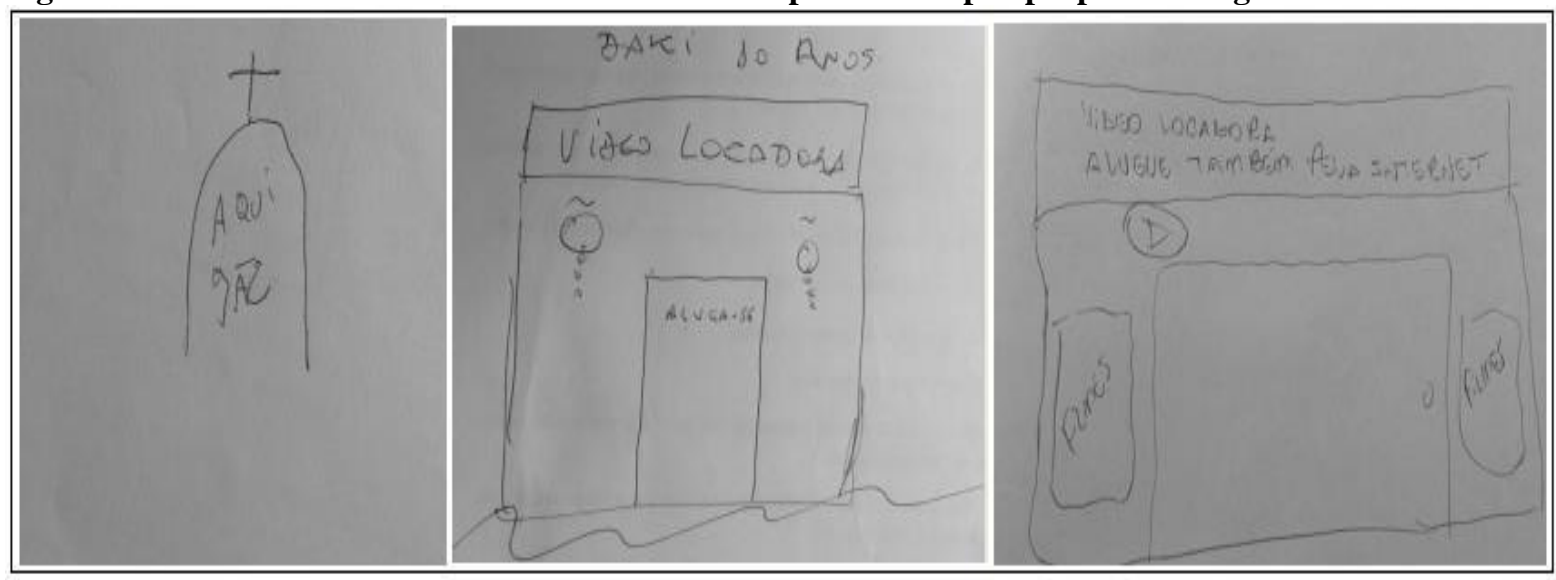

Fonte: dados da pesquisa.

Os entrevistados foram convidados a realizar um desenho representativo do futuro das videolocadoras, e seis aceitaram o convite. Os desenhos, em sua maioria, representam o fim das videolocadoras, resultado que corrobora os dados obtidos com as entrevistas. A Figura 2 apresenta três dos desenhos.

Os entrevistados aguardam um fim próximo para as videolocadoras tradicionais. $\mathrm{O}$ primeiro desenho (à esquerda) representa esse cenário que, segundo E6, está em crematório. O segundo (no meio) também mostra o fim da videolocadora, com um cartaz de "aluga-se" representando o que irá ocorrer em dez anos. Nesse desenho, E9 mostra tristeza com o fato e desenha lágrimas caindo da própria videolocadora. Finalmente, em uma perspectiva um pouco diferente, no terceiro desenho (à direita), E7 representa o futuro das videolocadoras como locação on-line, enxergando uma possibilidade de continuidade dos serviços de locação. Já os entrevistados E5 e E10 relatam verbalmente como representam esse futuro:

[...] um avião caindo [...] estamos na luta para chegar um avião do lado, que irá [...] dar combustível para ele começar a subir ou pelo menos estacionar [...] eu vejo como um avião querendo pousar, mas que está ali, perdeu uma turbina, mas está ali... está insistindo para a turbina voltar a funcionar. (E5)

Vai se tornar um museu, mas sempre vai ter um público, pode diminuir muito, mas sempre vai ter. (E10)

Mesmo vivendo o estágio do declínio organizacional das videolocadoras tradicionais, o gestor prático-avaliativo busca adotar práticas estratégicas alternativas que possibilitem o enfrentamento dos desafios competitivos 
que caracterizam o negócio de videolocadoras. Estes gestores interpretam que seu empreendimento ainda é viável e empreendem ações para evitar (ou postergar) a morte da organização. As práticas do gestor prático-avaliativo estão relacionadas no Quadro 3.

Quadro 3 - Práticas de enfrentamento do declínio organizacional por gestores prático-avaliativos.
\begin{tabular}{|l|l|}
\hline \multicolumn{1}{|c|}{ Práticas } & \multicolumn{1}{c|}{ Ações decorrentes da prática } \\
\hline 1. Investimento em qualidade & - Compra de lançamentos (filmes e séries) \\
\hline 2. Investimento em novas tecnologias & $\begin{array}{l}\text { - Compra de novas mídias disponíveis no mercado } \\
\text { (Blu-Ray) }\end{array}$ \\
\hline 3. Oferecimento de serviço & $\begin{array}{l}\text { - Busca pelo conhecimento do comportamento do } \\
\text { consumidor } \\
\text { personalizado aos clientes } \\
\text { clientes }\end{array}$ \\
\hline portfólio de produtos e serviços & $\begin{array}{l}\text { - Aluguel de jogos de videogame (lançamentos e } \\
\text { mais populares) } \\
\text { - Incorporação de outro negócio como, por exemplo, } \\
\text { a oferta de um espaço de lanchonete }\end{array}$ \\
\hline 5. Imitação da concorrência & $\begin{array}{l}\text { - Adoção de programas de fidelidade e pacotes } \\
\text { promocionais semelhantes à concorrência: pagamento } \\
\text { mensal para ter acesso a filmes ilimitados }\end{array}$ \\
\hline
\end{tabular}

Fonte: elaborado pelos autores

As práticas dos gestores práticoavaliativos mostram queas prescrições para cada estágio do declínio (WEITZEL; JONSSON, 1989) têm limites de aplicação em um cenário que abrange não apenas as videolocadoras, mas a própria indústria tradicional de audiovidual, que vem lidando com turbulências e, por isso, busca reinventar-se. O declínio e a mortalidade são vistos como resultados de inação ou falhas na ação, mas também podem ser abordados como situações que se originam de fatores incontroláveis e/ou inalteráveis pelos gestores. Isso traz implicações pessoais, organizacionais, econômicas e sociais distintas. Esta pesquisa mostra que o declínio de grandes empresas difere daquele das pequenas. Estas possuem poucos funcionários - em geral, membros da família. E sua história se confunde com a trajetória de vida do proprietário.

\section{CONCLUSÕES}

Em relação ao objetivo do artigo, foi analisado como os gestores de videolocadoras representam as tensões relacionais que surgem na relação empresamercado, especialmente aquelas tensões provocadas por novos concorrentes, inovações tecnológicas e mudanças no comportamento do consumidor, em um cenário que parece impor a extinção às 
videolocadoras ou a necessidade de se reinventarem. Essas tensões expressam as fortes mudanças ocorridas nas últimas décadas na indústria audiovisual e nas práticas estratégicas que as videolocadoras vêm adotando para prolongar o estágio do declínio. Esta pesquisa identificou dois perfis de gestores: o iterativo e o práticoavaliativo. E mostrou que as RS das tensões micro e macro moldam o "fazer estratégia" de proprietários-gestores de videolocadoras.

$$
\text { Nas representações do }
$$
macroambiente econômico e institucional, verificaram-se as seguintes práticas: falta de fiscalização por parte das instituições responsáveis, omissão por parte do Estado e ação de instituições ou pessoas que desempenham atividades ilegais de produção e distribuição de obras audiovisuais. Todas essas práticas promovem pontos comuns de ação e interagem (JARZABKOWSKI, 2004) com aquelas que acontecem no nível micro. As micropráticas identificadas estão relacionadas com as RS de cada gestor sobre as adversidades no nível macro e o quanto essas atravessam e rompem com identidades sociais construídas: a adoção de promoções, as práticas de melhorar substancialmente o atendimento aos clientes, a venda de novos produtos em sua videolocadora, como os jogos para videogame, chegando à diversificação de atividades comerciais.

Para ambos os perfis de gestoresproprietários, as $\mathrm{RS}$ relativas às macroinfluências moldam de maneiras diferentes os comportamentos e as práticas dos entrevistados. Em relação ao futuro das videolocadoras, foi possível notar que a maioria dos entrevistados não espera uma reversão do processo de virtualização do setor de vídeos domésticos e espera deste uma morte anunciada, alguns já vivendo o luto dessa morte. Outros, por sua vez, representam essa morte como possibilidade de renascimento para um tipo de negócio diferente do modelo tradicional de videolocadoras.

Esta pesquisa suscita variadas possibilidades de estudos futuros. Dentre eles, a ampliação para outras regiões do país poderia propiciar a análise comparativa de influência de elementos regionais e culturais não abordados aqui. Estudos futuros sobre locadoras também podem oferecer uma compreensão de aspectos diversos que sustentam a longevidade de empresas no setor. Afinal, segundo dados do IBGE (2012), apenas 10,7\% dos municípios brasileiros possuem cinema, o que contribui para a locação de filmes caseiros; ademais, as salas estão concentradas nas grandes cidades, dificultando o acesso de uma parcela 
substancial da população (FILHO et al., 2014). A pesquisa do referencial teórico mostrou um diálogo incipiente das interdependências e das práticas entre o declínio da indústria e o declínio das organizações que nela atuam. Estudos futuros que busquem o diálogo entre a literatura do ciclo de vida da organização e a perspectiva da estratégia como prática exigirá dos autores o enfrentamento de divergências epistemológicas. Outro tema para estudos futuros diz respeito ao luto nas organizações relacionado às vivências da mudança e do declínio organizacionais, haja vista o paradoxo, mostrado na pesquisa, de que as representações de morte e de longevidade não se excluem mutuamente. 


\section{REFERÊNCIAS}

ANCINE - Agência Nacional do Cinema. Vídeo doméstico: Mapeamento - Agência Nacional do Cinema, 2010. Disponível em: <http://www.ancine.gov.br/media/ SAM/Estudos/Mapeamento_VideoDomestico_Publicacao.pdf>. Acesso em: 23 dez. 2015.

BARDIN, L. Análise de conteúdo. Lisboa: Edições 70, 2009.

BORGES, J. F., MEDEIROS, C. R. O., CASADO, T. Práticas de gestão e representações sociais do administrador: algum problema? Cadernos Ebape.BR, v. 9, n. 5, p. 531-563, 2011.

BRADSHAW, T. Netflix bate 100 milhões de assinantes com adesão fora dos EUA em alta. Jornal Folha de S. Paulo, 18 set. 2017, traduzido de Financial Times, por Paulo Migliaci. Disponível em: <http://www1.folha.uol.com.br/mercado/2017/07/1902157-netflix-ganhaforca-com-adesao-de-assinantes-fora-dos-eua-e-acoes-sobem.shtml.> Acesso em: 19 set. 2017.

CAMERON, K. S.; WHETTEN, D. A.; KIM, M. U. Organizational dysfunctions of decline. Academy of Management Journal, v. 30, n. 1, p. 126-138, 1987.

CAMERON, K. S; KIM, M. U.; WHETTEN, D. A. Organizational effects of decline and turbulence. Administrative Science Quarterly, v. 32, n. 2, p. 222-240, 1987.

CAMERON, K.; ZAMMUTO, R. Matching managerial strategies to conditions of decline. Human Resource Management, v. 22, n. 4, p. 359-375, 1983.

CARRIERI, A. P.; MURTA, I. B. D.; TEIXEIRA, J. C.; SOUZA, M. M. P. Estratégias e táticas empreendidas nas organizações familiares do Mercadão de Madureira (Rio de Janeiro). Revista de Administração Mackenzie, v. 13, n. 2, p. 196-226, 2012.

CAVEDON, N. R.; FERRAZ, D. L. S. Representações sociais e estratégia em pequenos comércios. Revista de Administração Eletrônica RAE, v. 4, n. 1, p. 1-18, 2005.

CHIOU, L. The Timing of movie releases: evidence from the home video industry. International Journal of Industrial Organization, v. 26, n. 1, p. 1059-1073, 2008.

CASTRO, D. Concorrência Assimétrica. Netflix dobra tamanho em um ano e já fatura mais do que o SBT. Blog Notícias da TV, de 13 dez. 2016. Disponível em: <http://noticiasdatv.uol.com.br/noticia/mercado/netflix-dobra-tamanho-em-um-ano-e-jafatura-mais-do-que-o-sbtb--13507\#ixzz 4SlqWc7eV>. Acesso em: 20 dez. 2016. 
COLOMBO, S. Uma ditadura cinematográfica está se impondo, diz dona da locadora 2001.

Jornal Folha de S. Paulo. Disponível em: <http://www1.folha.uol.com.br/ilustrada/ 2015/12/1721632-uma-ditadura-cinematografica-esta-se-impondo-diz-dona-da-locadora2001.shtml>. Acesso em: 23 dez. 2015.

CORREA, A. M. H. et al. Soldadinhos-de-chumbo e bonecas: representações sociais do masculino e feminino em jornais de empresas. RAC [on-line], v.11, n.2, p. 191-211, 2007.

D'AVENI. The Aftermath of organizational decline: a longitudinal study of the strategic and managerial characteristics of declining firms. Academy of Management Journal, v. 32, n. 3, 1989.

DENZIN; N. K.; LINCOLN, Y. O planejamento da pesquisa qualitativa. Porto Alegre: Artmed, 2010.

DINIZ, A. P.; CARRIERI, A. P.; BARROS, A. N. Invisibilidade social e trabalho noturno: reflexões a partir de representações sociais de garçons. Revista Gestão \& Planejamento, v. 14, n. 1, p. 18-38, 2013.

DURAN, M. C. G. Representações sociais: uma instigante leitura com Moscovici, Jodelet, Marková e Jovchelovitch. Educação \& Linguagem, v. 15, n. 25, p. 228-243, 2012.

EMIRBAYER, M.; MISCHE, A. What is agency? The American Journal of Sociology, v. 103, n. 4, p. 962-1023, 1998.

ENOQUE, A. G.; BORGES, J. F.; BORGES, A. F. Representações do Lucro no Comércio de Artigos Religiosos: interpretações do sagrado e do profano no cotidiano das organizações. RECADM, v. 13, n. 3, p. 372-392, 2014.

FELDMAN, M. S.; ORLIKOWSKI, W. J. Theorizing practice and practicing theory. Organization Science, v. 22, n. 5, p. 1240-1253, 2011.

FIGUEIREDO, M. D.; CAVEDON, N. R. O espaço dos indesejáveis. A circularidade da representação de estigma em um centro comercial de Porto Alegre. Civitas, Porto Alegre, v. 12, n. 3, p. 579-594, 2012.

FILHO, E. M. G.; BOTELHO, F. B.; REZENDE, B.; BRASIL, E.; ARASHIRO, T.; PAIVA, A.; CHIAVENATO, D. O impacto econômico do setor audiovisual brasileiro. Motion Picture Association América Latina, 2014. Disponível em: 
<http://www.fncp.org.br/web/download/impacto_economico_do_av_bra_mpa_sicav_tendenci as.pdf>. Acesso em: 07 dez. 2015.

FLICK, U. Entrevista episódica. In: BAUER, M. W.; GASKELL, G. (Orgs.), Pesquisa qualitativa com texto, imagem e som: um manual prático. Petrópolis (RJ): Editora Vozes, 2003. p. 114-136.

GONÇALVES, J. E. L. A necessidade de reinventar as empresas. RAE, v. 38, n. 2, p. 6-17, 1998.

GUERRA, G. C. M.; TATTO, L. As representações sociais da estratégia no ramo hoteleiro.

Revista Hospitalidade, v. 7, n. 1, p. 79-105, 2010.

HERMANN, L. A convergência midiática e as mudanças comportamentais no consumo do mercado de nicho: Netflix e a "desmaterialização" dos produtos. ANIMUS - Revista Interamericana de Comunicação Midiática, v. 11, n. 22, p. 222-245, 2012.

IBGE - Instituto Brasileiro de Geografia e Estatística. Pesquisa dos Municípios Brasileiros. 2012. Disponível em: <ftp://ftp.ibge.gov.br/Perfil_Municipios/2012/munic2012.pdf>. Acesso em: 05 dez. 2015.

JARZABKOWSKI, P. Strategic practices: an activity theory perspective on continuity and change. Journal of Management Studies, v. 40, n. 1, p. 23-55, 2003.

JARZABKOWSKI, P. Strategy as Practice: Recursiveness, adaptation, and practices-in-use. Organization Studies, v. 25, n. 4, p. 529-560, 2004.

JARZABKOWSKI, P.; BALOGUN, J.; SEIDL, D. Strategizing: the challenges of a practice perspective. Human Relations, v. 60, n. 1, p. 5-27, 2007.

JARZABKOWSKI, P.; WHITTINGTON, R. Hard to disagree, mostly. Strategic Organization, v. 6, n. 1, p. 101-106, 2008.

JODELET, D. Representações sociais: um domínio em expansão. In. Jodelet, D. (Org.). Representações sociais. Rio de Janeiro: EdUERJ, 2001. p. 17- 44.

JOHNSON, G.; MELIN, L.; WHITTINGTON, R. Micro Strategy and Strategizing: Towards an Activity-Based View. Journal of Management Studies, v. 40, n. 1, p. 3-22, 2003. 
LIMA, D. I. Os últimos dos moicanos. Jornal Folha de S. Paulo, A18, 2 nov. 2015.

MINTZBERG, H.; AHLSTRAND, B.; LAMPEL, J. Safári de estratégia. Porto Alegre: Bookman, 2000.

MORGAN, G. Imagens da organização. São Paulo: Atlas, 2000.

Paradigms, metaphors, and puzzle solving in organization theory. Administrative Science Quarterly, v. 25, n. 4, p. 605-622, 1980.

MOSCOVICI, S. Representações sociais. Petrópolis, RJ: Vozes, 2007.

NICOLINI, D. Zooming In and Out: Studying Practices by Switching Theoretical Lenses and Trailing Connections. Organization Studies, v. 30, n. 12, p. 1391-1418, 2009.

NORDICITY. The economic contribution of the film and television sector in Canada. 2013. Disponível em: <http://mpa-canada.org/downloads/MPA-Canada_Nordicity-Report_July2013_English.pdf>. Acesso em: 26 dez. 2015.

RASCHE, A.; CHIA, R. Researching strategy practices: a genealogical social theory perspective. Organization Studies, v.30, n.7, p.713-734, 2009.

SALLES, D. M.; COSTA, I. S. A. Representações do trabalho: estudo sobre confinamento na indústria petrolífera. Revista de Administração de Empresas, v. 53, n. 3, p. 230-242, 2013.

SEIDL; D.; WHITTINGTON, R. Enlarging the Strategy-as-Practice Research Agenda: Towards Taller and Flatter Ontologies. Organization Studies, p. 1-15, 2014.

SILVA, A. R. L.; CARRIERI, A. P.; JUNQUILHO, G. S. A estratégia como prática social nas organizações: articulações entre representações sociais, estratégias e táticas cotidianas. R.Adm., v. 46, n.2, p.122-134, 2011.

SILVA, L. F.; LOPES, M. S.; OLIVEIRA, P. S. G. A mudança no mercado de videolocadoras sob a perspectiva da ecologia das populações organizacionais. Revista Ciências Sociais em Perspectiva. v. 12, n. 22, p. 1-19, 2013.

SILVERMAN, D. Interpretação de dados qualitativos. Porto Alegre: Artmed, 2009. 
SPINK, Mary Jane P. O conceito de representação social na abordagem psicossocial. Cad. Saúde Pública, v. 9, n. 3, p. 300-308, 1993.

PORTAL TERRA. Para sobreviver, videolocadoras vendem até bicho de pelúcia. Disponível em:<http://economia.terra.com.br/vida-de-empresario/para-sobreviver-videolocadorasvendem-ate-bicho-de-pelucia,cf07414fce123ce19f10aff61d1ef05f0fkgRCRD.html>. Acesso em: 08 dez. 2015.

VAARA, E; WHITTINGTON, R. Strategy as practice: taking social practices seriously. Academy of Management Annals, v. 6, n. 1, p. 285-336. 2012.

VERGARA, S. C. Métodos de pesquisa em administração. São Paulo: Atlas, 2006.

WEITZEL, W.; JONSSON, E. Decline in organizations: a literature integration and extension. Administrative Science Quarterly, v. 34, n. 1, p. 91-109, 1989.

WHETTEN, D. A. Organizational decline: a neglected topic in organizational Science. Academy of Management Review, v. 5, n. 1, p. 577-588, 1980.

WHITTINGTON, R. Completing the practice turn in strategy research. Organization Studies, v. 27, n. 5, p. 613-634, 2006.

WILSON, D.C. JARZABKOWSKI, P. Pensando e agindo estrategicamente: novos desafios para a análise estratégica. RAE, v. 44, n. 4, p. 21-31, 2004. 